Vol. 5, No. 2, 2019

Yuliia Frolova

\title{
NETWORK OF THE OTTOMAN FORTIFIED SETTLENTS ON THE NORTHWEST BLACK SEA COAST IN THE XVII AND XVIII CENTURY
}

\author{
Department of Architecture and Restoration \\ Lviv Polytechnic National University, Ukraine \\ frolova@protonmail.com \\ ORCID:0000-0003-0436-666X
}

Received: 02.09.2019/Revised: 14.11.2019/Accepted: 22.11.2019

(C) Frolova Y., 2019

\begin{abstract}
The article is aimed at covering the issue of the historical organization of the network of fortresses of the northwest coast of the Black Sea and the Danube-Dnepr intermarriage during the XVII and XVIII centuries, the times of subordination of this territory to the Ottoman Empire and vassal states. The study covered 11 cities that had fortification systems. Historiographical and descriptive documents on fortifications were systematized, search for common features and algorithms for the formation of a fortified area was compared with other known Ottoman cities of the same period. Generalization of architectural solutions is derived in a spatial typology.
\end{abstract}

Key words: city planning, fortress, defense lines, The South of Ukraine, fortified settlements, north-west coast of the Black Sea, ottoman fortress, XVIII century

\section{Introduction. Overview of the level of research of the issue}

The general direction of the study. The description of the architectural and spatial planning of the fortified cities is part of an interdisciplinary study of the historical - urban, cultural - social and economic geographical development of the southern region of modern Ukraine. The art of fortification during the XVI and XIX centuries was an important factor in influencing the development of the area, a factor of spatial and architectural filling of the urban environment, social and cultural diversity, and symbolized the milieu and political power of the countries. The major cities of the northwest coast of the Black Sea, under socio-economic and political circumstances, had fortifications that strengthened and fixed the strongholds of statehood.

In 2010, a translation of one of the most interesting monographs of the last decade on the history of the Black Sea was published. This attempt to unify the historical heritage of a large number of states within a probable dating period brings the researcher into the space of universal civilization value of a geographical unit - the sea. According to the author, possession of the Black Sea was and is a decisive factor in the establishment of the statehood of the two Great Empires, the Ottoman and the Russian; the desire of principalities and communities to control at least a small proportion of the coastline. (King, 2004). These aspirations and decisive political steps have led to a constant change in the territorial integrity of the coast, militaristic and social conflicts, the start-up and prosperity of individual communities, and the creation of a large number of political myths. Competition over the control of the Black Sea waters of the Ottoman Empire and the Russian Empire for two centuries, from the beginning of the XVIII to the end of the 19th, prompted both states 
to take decisive action for consolidation and expansion. The Ottoman Empire built its control by subjugating the territory to the vassal of the Crimean and Naga Khanate, which was supposed to be the protection of the interests of the Muslim world; The Russian Empire built an expansive policy on the mythological and logical liberation of the Christian community. The influence of the Nogai Khaganate of Bessarabia, the Crimean Tatar Khanate of the Ochakov Steppes and the Dnieper Hetmanate was considered to be a component of separate political programs against the background of such a prolonged conflict of imperial interests (Gribovsky, undated). Only in recent years is the territory of the Northern Black Sea Uzbekistan explored as part of a much broader concept of the Steppe Edge, the Euro-Asian front.

Frontier comparativism in historical science views Budzhak, Bessarabia and the Ochakov steppes not as separate border territories between East and West, a buffer zone between Christianity and Muslims, a "wild steppe" - but as a multicultural space of interconnectedness and modality. The emergence of the Cossacks as a "phenomenon" is directly related to the decision of the state border issues of protection and control of the Polish-Lithuanian Kingdom (Chernovol, 2016), as well as the program of the Russian Empire forcibly settling the territory of the Ukrainian-Cossack people on the territory between Ukrainian and Dnieper line. The boundary, boundary term is largely a limiting tool when considering a potentially variable territory. In the context of global history, political boundaries have never been in the state of a fixed geometric unit, and have intentions for temporality. Border, border can be used as a political and documentary expression directed at the fixation of a specific territory under the protection of a single state, while the space of cultural, ethnic and social ties can mutually penetrate from one state and society to another. It is clear that history does not excuse the conventions and consolidation of concepts, and concretization of facts and logical construction of conclusions is a critical task for research.

The territory of the Danube, Dniester and Dnieper rivers is already becoming more than just a multicultural and free region, and the center of a multi-layered history with influence on the development of 8 states over 5 centuries: the Ottoman Empire, the Moldovan and Romanian principalities, the Crimean and Nagoya Khanate/ The Hetmanate, the Russian Empire. It is necessary to consider this region not only from the standpoint of historical events of an individual state, but in the aggregate, building a complex non-linear model of development.

Since the end of the XIX century, a new conceptual vision of the essence of cultural and political interaction of different states - the theory of the comparative front - has been introduced into international historical science; (Chernovol, 2016).

Formation of time and limits of research. In the XVI and 1XVII centuries, the frontier of the MuslimOttoman Ottoman Empire and Christian Europe was formed, starting from the Spanish provinces in Algeria and Tunisia, along the Mediterranean, Dalmatia, Croatia, Hungary, the Polish-Lithuanian region and the line in the Beirut region and Ukraine. Muscovy. Alfred Riber, wrote this On the development of the Northern Black Sea was largely:

- The Habsburg Front, which passed through the territory of the Winger Principality and the Commonwealth, along the Transdunabia Mountains and the Danube and Dniester rivers, found significant changes in the organization of the border - most European cities which had previously been fortified by the principles of the latest inventors of the militaristic revolution (Gábor, 1998). Not all cities could afford the modernization of the fortifications; the first line of reconstruction was the cities (Szigetvár, Kanizsa, Gyõr, Komárom, Érsekújvár, Eger, and Temesvá (Gábor, 1998), the main fortress-city being Wina. frames become Belgrade (Fig. 1).

- Ochakov steppes, Dniester and Dnieper rivers. They were almost entirely subordinated to the Golden Horde Khanate, which in the 16th century became part of the vassal duties of the Ottoman Empire. (Fig. 2).

- Eastern border with the Muscovy / Russian state along the Don and Caucasus rivers. The territory under study was included after the administrative regulation of the Ottoman Empire in the Budzhak and Ochakov districts (the territory is restricted today by the rivers Danube, Prut, Dniester, Dnieper and the Black Sea. (Fig. 2). 


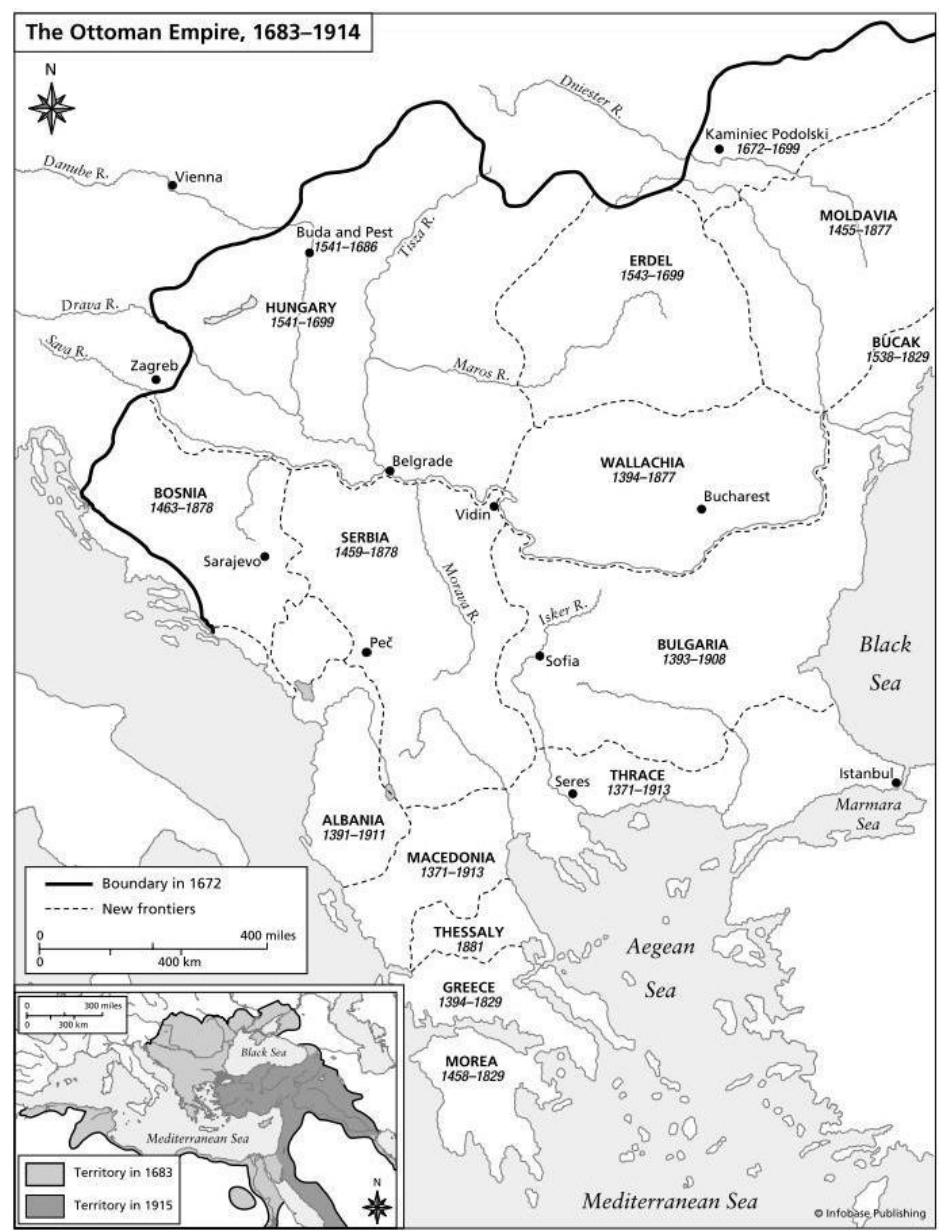

Fig. 1. Ottoman-Hasburg frontier after Gabor Agoston (Gabor, A., Masters, B., 2009)

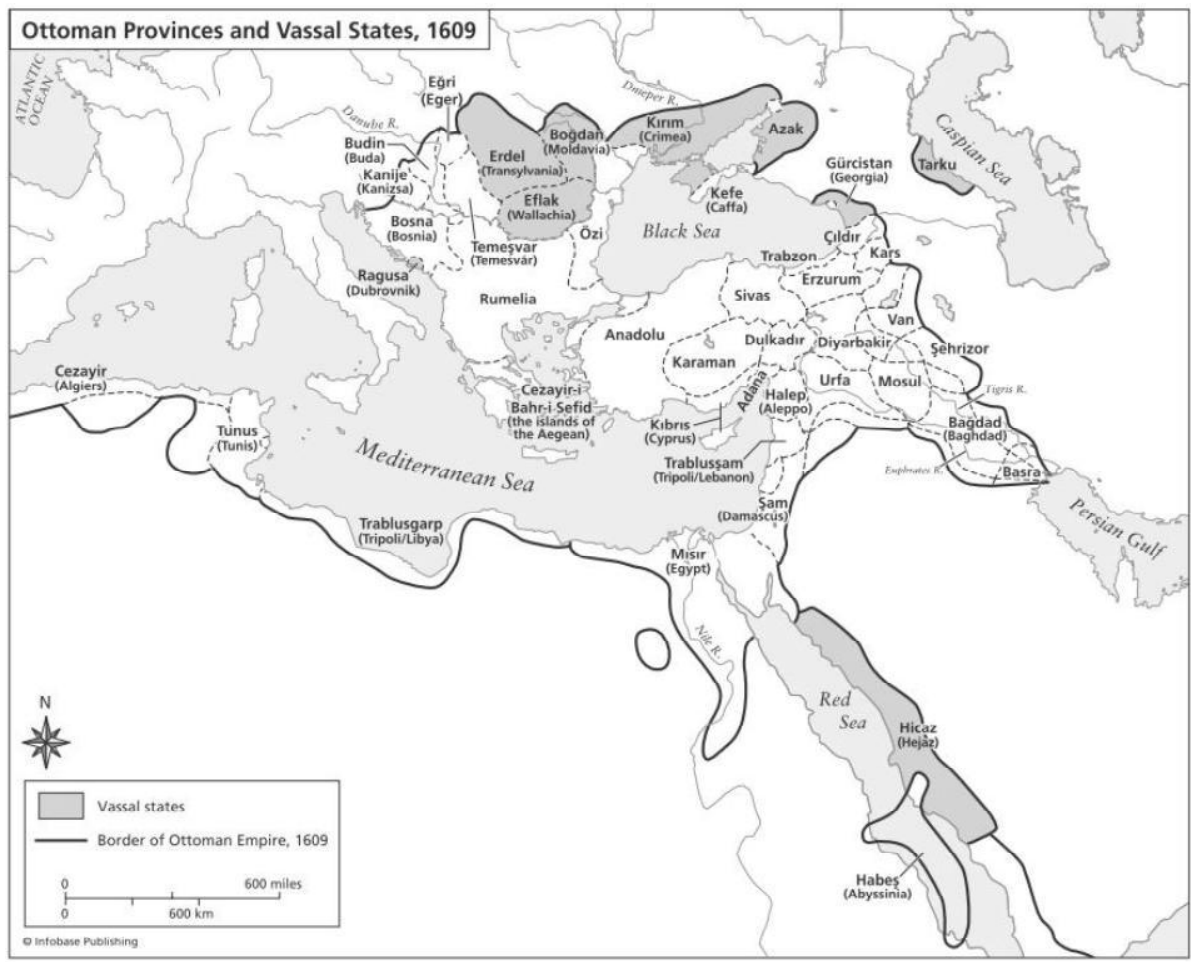

Fig. 2. Ottoman provinces and vassal states after Gabor Agoston (Gabor, A., Masters, B., 2009) 


\section{The degree of study of the region by Ukrainian scientists}

Due to the biased interpretation of the history of the Tatar and Ottoman periods of domination of the 17-18 centuries and the finding of a large part of the source base in the archives of modern Russia, the speed of work on the search for a common non-conflict history is suspended. Documents that were evacuated during World War II to Moscow and St. Petersburg are still limited access for Ukrainian researchers. Known to the $\mathrm{XX}$ century, the published references testified only to the political weakness, incompetence of the local administration of the Ottoman Empire, and the slowness of decision-making on the construction of fortifications during the Russo-Ottoman wars by the Crimean Khanate. The skeptical attitude of the victorious country to the heritage of previous generations has pushed important features of the urban culture of the Ottoman Empire and the Crimean Khanate beyond the history of the Liberation State. An argument that is now refuted, cities and settlements begin to take root from a typical project developed in the Russian Empire (Shkvarykov, 1954) (Brunov II, Vlasyuk, Kaplun, Kiparisova, Maksimov, Chinyakov, 1956), (Hubar, 2015), and the city comes into force precisely at the will of Catherine II. Small Ottoman cities and settlements are hardly reflected in the modern history of cities in southern Ukraine (Timofienko, 1996), or mentioned in part (Timofienko, 1986).

Contemporary archeological, urban and historical studies review Soviet-formed theories and hypotheses about the myth of the land of the desert and backward, which are still based on the political propaganda of the Russian Empire. The impetus is the publication of Timofiyen-ko (Timofiyenko, 1986) and the staff of the scientific monograph "Monuments of Urban Planning ..." (Logvin GN, EM Godovanyuk. IM Kravets, IR Mogytych, TA Tregubova, 1985). Contemporary Ukrainian historiography seeks to find and integrate European-Asian sources in the history of the country's development that were not previously in the scientific circulation of the country Şlapac, M., (2004, 2016), A. Sereda (Wednesday, 2009), I. Kissé (ed., 2016), I. Sapozhnikov (Sapozhnikov, 2017) (Yacubova, undated), A. Krasnozhen $(2018,2019)$

Over the past two decades, foreign documents and cartographic sources have been published to supplement previous research (Timofienko, 1986) of urban development in southern Ukraine. To the international circle of scholars whose publications concern the formation and development of Ottoman and Tatar settlements, Ostapchuk (Finkel, Caroline and Victor Ostapchuk, 2005), Finkel (Finkel, Caroline and Victor Ostapchuk, 2005) Fedacar (Fedakar, 2015), S.Belyaeva (Ostapchuk V., Bilyayeva S., 2009), Şlapac, M., (2004, 2016), Even these numerous interdisciplinary studies of urban development and the architectural features of settlements are fragmentary, highlighting particular periods or finds. Higher-ups are mostly based on archaeological research and historiographical comparisons.

\section{The problem of research}

Town-planning studies in the territory of the South of Ukraine were carried out in the 1970s when the encyclopedic monograph "Monuments of town-planning..." was prepared (Logvin GN, EM Godovanyuk. IM Kravets, IR Mogytych, TA Tregubova, 1985), in the volume dedicated to Odessa, Mykolaiv and Kherson regions, 12 cities and towns have historical and urban significance. A separate appendix describes what kind of historical heritage items fall into the category of protection. These are estates, general planning, sacral structures, monuments. Only in one case is a fortification or fortress separately described. The town-planning significance of fortifications has been thoroughly researched and substantiated by experts who have examined the western and central regions of Ukraine (M. Bevz, G. Petrishin, O. Osichenko), considering the period of Ukrainian history from the Galicia-Volyn principality to the Commonwealth European cultural heritage. Separate consideration is the border fortifications that have long been the subject of common interest of both cultural currents of the Ottoman and Habsburg Empires. It is on the frontier professionals in the history of fortification that show a strong development of fortifications, design and planning decisions. At the same time, the territory of the north-west-west coast of the Black Sea remains in the area of tangible consideration of studies of cities and fortresses, which is more similar to the overall summation of the conclusions about the history of the Moldavian and Romanian, Lithuanian principalities, or the territory of the buffer border between 
the rivers Khanate. separation of the historical and theoretical description of cities from architectural and spatial organization, the need to materialize models of cities as spatial models. To find commonalities and network connections as they relate to the general context of the Ottoman Empire. Problems of joint dating, development and spatial organization.

The purpose of the article. The aim of this paper is to summarize the principles of territorial and planning organization of the fortifications of the Ottoman Empire in order to prove the system and coherence of the created fortification network by the 18th century.

General Methods used mapping, blueprints, simulations, andthiographic and descriptive data. Methods Summary. To form a model of architectural and planning development of selected fortifications in the cities of Izmail (bastion fortress Izmail), Kiliya (medieval and bastion fortress Kiliya), Belgorod-Dnistersky (medieval fortress Ak-kerman), Ochakov, Kutuzon fortress a graphical restoration of the fortifications fortifications was carried out on an evolutionary principle, the factors of formation of spatial structures were analyzed, and the characteristic features of the objects were identified. Photo-fixing and mapping of the remains of fortifications were made, sketches of the environment were made, graphical analysis of drawings and lithographs were made, 3D models of fortresses were constructed according to historical plans and graphic reconstructions of views of the main structures were developed. In total, 11 fortification sites were selected: Kiliya fortress, Ishmael, TatarBunar, Ak-Kermen, Ajider fort, Yeni-Dunia fortress and Hajjbeey fortress, Ozu fortress, Kinburun fort, Perekop fortress. The island fortresses of Berezan and Alexander. The following are to be attributed to the Ottomans: Kiliya, Ishmael, Ozu, Ak-Kerman, Perekop, Kinburun, Tatar-Bunar, Yeni Dunia, or Hajibey

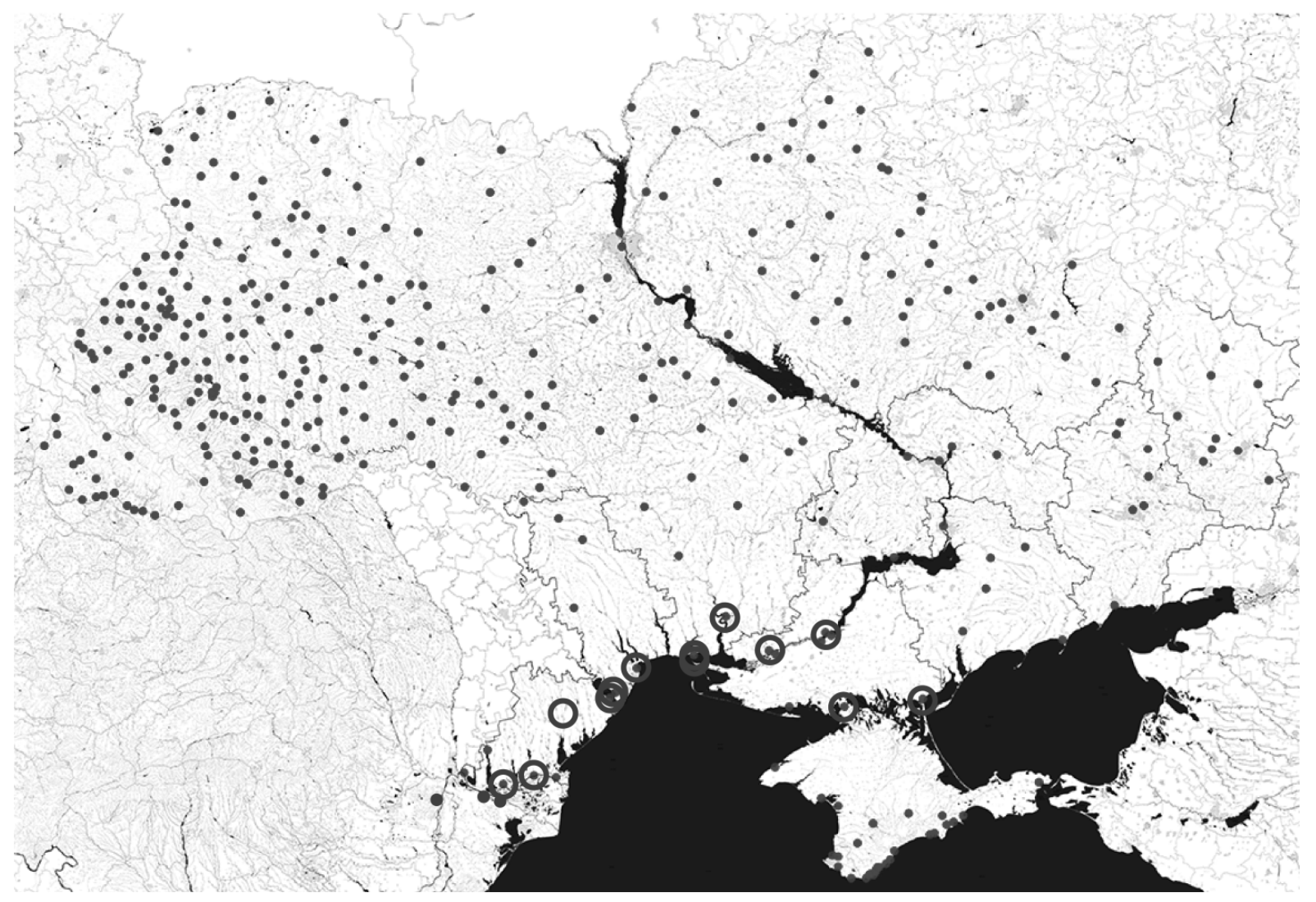

\section{- $\quad$ 1. Historic settlements \\ (2. Investigating areas \\ - 3. Addition investigating areas}

Fig. 3. Map of Ukraine historic settlements after the Law. With marked invastigating areas 


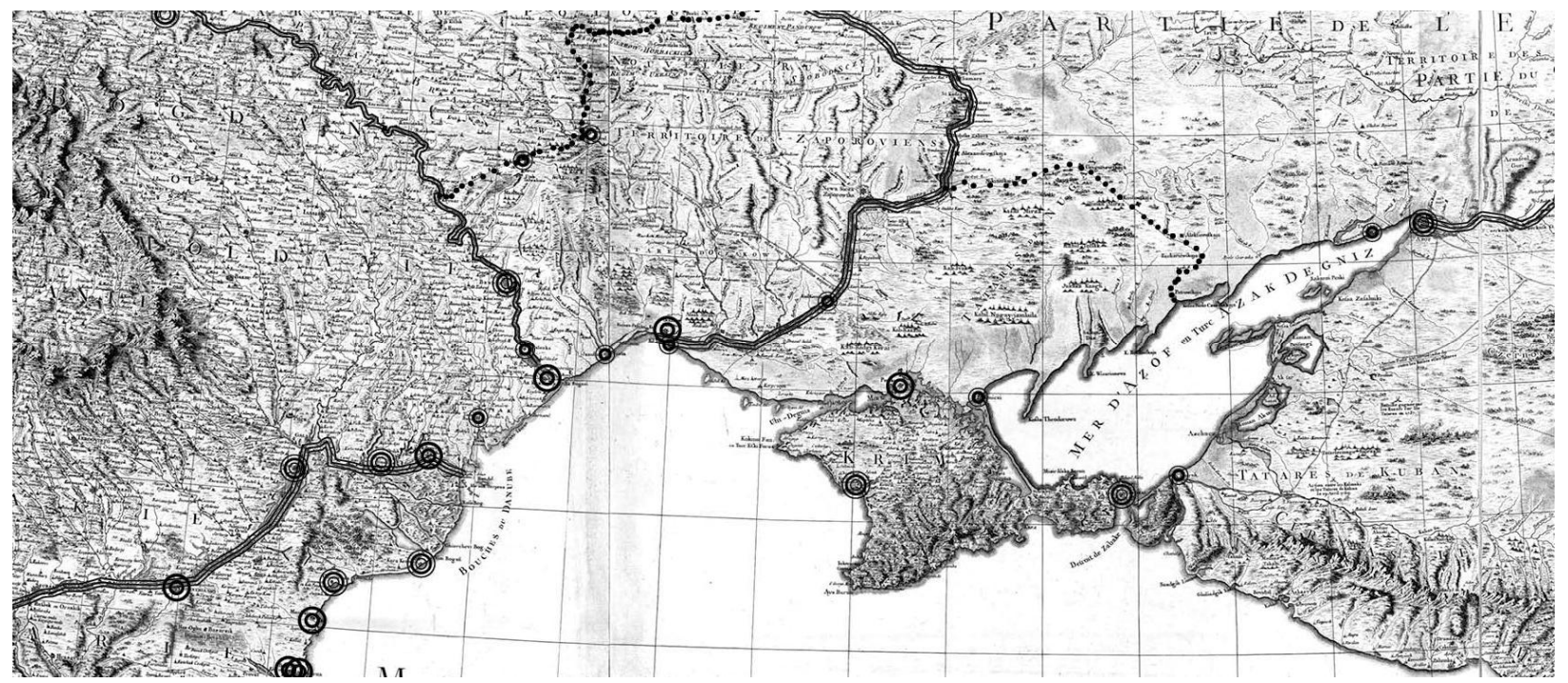

Fig. 4. Map of fortified settlementscreated by Rizzo Zannoni.

\section{Natural and geographical factors of territorial influence}

Subordinate to the vast open spaces of Budzhak and Bessarabia, the military might of the Ottoman Empire is rooted in the Habsburg Front and the European annual network that had access to the Inland Sea of the Empire - the Black Sea. Topographic corridors passed to the steppe territories and watersheds; natural relief serves as a formal marker of demarcation. While controlling the Bosphorus and Dardanelles straits, the states did not build complex schemes for territorial control of the vassal regions; instead, the location of key forts was intended to control the deltas of large transport rivers that served trade routes.

The geographical location of fort posts on rivers and watersheds formed the following types of subordination and interaction between elements of fortified territories:

1) gate type (F. Ozu, F. Kinburn, F. Hassan Pasha; F. Kazikermen, F. Aslan-Kermen; F. Ki-lia, F. Isakcha). It is characterized by the location along the course of rivers or small reservoirs and river deltas, so as to close the battle space between the two fortresses. Provides coherence in defense decisions, shared water corridor (Fig. 5).

2) mirror type (F. Hotin). The fortress is located as a counter to another fortress (Fig. 6).

3) a chain type (the fortresses of the Dniester and Danube rivers). The location of fortresses along the course of rivers or reservoirs, with a common function of common control over a river corridor, with a model of joint interaction: invasion, disturbance and sub-rtquest signals (Fig. 7).

4) the combined type. Considered as a collection of all the above types, with the replacement or addition of another element.

\section{Hierarchical and economic factors affecting fortification objects}

Subordinate administratively and territorially, who also had a partial right of local self-government. Three levels of communication have been identified: 1) main - Istanbul (capital) - Si-listria (Kale, the capital city-fortress of the region); 2) minor - kale (the main city fortress of the region) - kale (fortresses, fortified cities, fort posts); 3) subordinate - Kales (fort-these, fortified cities, fort-posts) - palanches, tabiyas, fortified territories. The fortified territories of the fortress were gradually formed in the suburbs, which were later strengthened by the retransmission and included in the administration of the fortress. There are examples of 2 and 3 lines of retransmittal strengthening of the mediocrity (F. Ochakov, F. Ak-Kerman, F. Khotyn, F. Kiliya).

\section{Artistic and cultural factors of influence}

According to Islamic tradition, considerable attention was paid to the compositional expression and adaptation of the canon of the Grand Tower (burj) as a major element of fortification. Thickening of the walls of the fortress was also added to the canon by the Ottomans to counter the weapons of the enemy. 

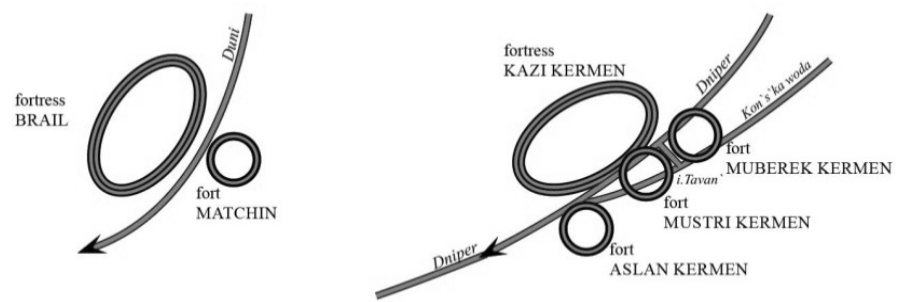

\section{GATE TYPE}

OF SPATIAL AND NETWORK LOCATION

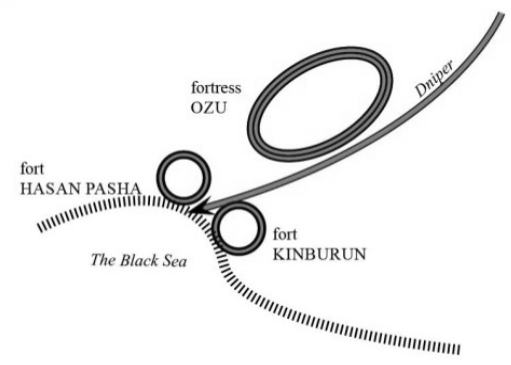

Fig. 5. Gate type
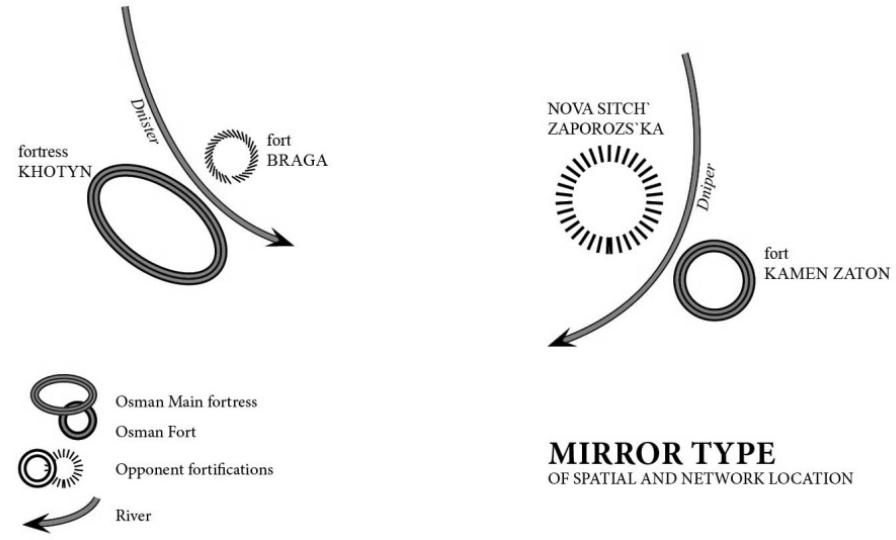

MIRROR TYPE

\section{MIRTOR TYPE}

Fig. 6. Mirror type

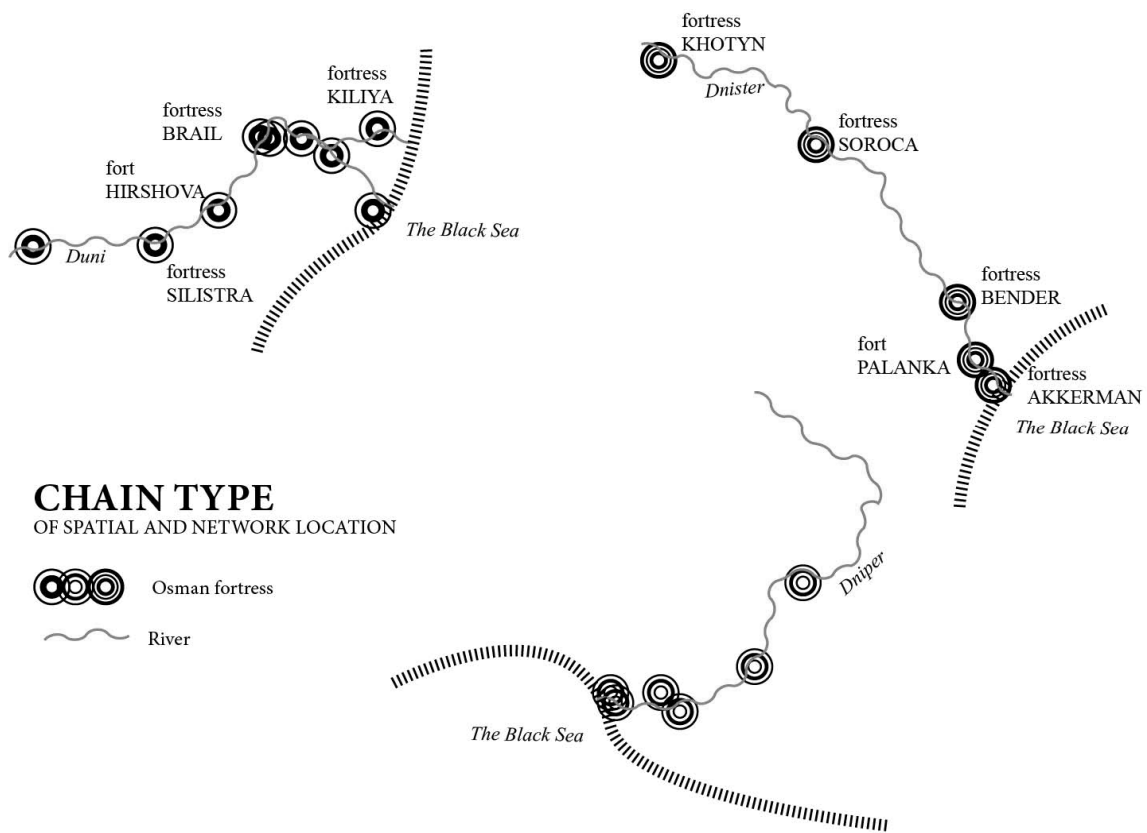

Fig. 7. Chain type 
By the 16th century, significant changes had taken place in the fortification of the Ottoman Empire, Most of the fortresses were simple rectangular garrisons of the fortress in a typical project. (Nicolle, 2010). The high stone walls were largely used, already old-fashioned, in comparison with the European bastina forts. Such an influence on architectural spatial decisions had a fabulous ghost of the acquisition of Constantinople, and its aesthetic representation in the culture of the Ottomans. Con-stantinople, as the most powerful fortress in the city, where the walls are three-tiered and have large gates, square and polygonal towers, the pattern and colors of the walls are the same as the national colors of the empire - red and white. Citadel of Galata the prototype of the Great Tower.

In the early stages of fortification, the Ottoman Empire adapted the fortification elements (Genoese citadels, Lithuanian castles, field fortifications) by its own cultural principles at that time - not to destroy and enhance the cultural features of the area. Due to the "no damage" approach, significant layers of historical landscapes have survived - the Genoese-Venetian presence on the Black Sea, Lithuanian towers and Nogai-Tatar settlements. The alterations concerned only religious and symbolic structures.

Fortresses of southern Ukraine con. XVII - middle of the XIX century. also characterized by restructuring and reconstruction of previous construction periods for the needs of the Ottoman Empire. The experience of local masters was used, and the traditions of the Ottoman semantic filling of the fortification objects (the White Tower - Galatasaray Tower, the city walls - the walls of Constantine Istanbul) were integrated into the space of the previous settlements laconically, preserving the fabric of the city and its ethnic features. The modernization and transition of the fortification planning solution from medieval methods of construction to bastion tenals of the tonal type was influenced by Franco-Ottoman political relations after the first attempts to modernize the Ottoman army in the XVIII century. The major changes take place on paper, with the modernization projects touching on much later, almost at the end of the XVIII century. Rebuilding of the fortresses by the French and Austrian schools of fortification of the tonal and bastion type of fortifications was implemented with considerable inhibition and obstacles among the military. Low earthen bastions and stone moats, stone walls of medieval citadel, adapted to administrative functions, lines of defense complemented by new form-ravelins and redans.

The towers and gates of the medieval Ozu and Kilia fortresses are completely dismantled and replaced by earthen bastions with moats and polysades, the citadel fortresses are used as administrative structures or ancillary buildings, gradually being completely dismantled. The street layout grid switches to a regular rectangular or beam. The surroundings of the fortress are adapted to the voice, increasing the defensive fortifications, small earth bastions replacing the stone towers. The Kinburn Fortress is being rebuilt according to the French Fortification School and strengthened by the Ravelin auxiliary from the Dnieper Estuary.

\section{Conclusion}

It was established during the study that not all fortifications have any available drawings of plans, sufficient source and research base, partially missing lithographs of later periods of remodeling, records of archaeological investigations of the fortification sites in the early twentieth century, which in turn directs researchers to expand international source search and collaboration. At present, the types and features derived are based on preliminary considerations and hypothetical conclusions, and the spatial organization models themselves should be specified in the original.

The territories designated as the steppe European frontier between the East and the West are accompanied by a developed system of fortifications that are significantly different from the European fortification tradition of fortification. Fortresses and fortified cities are located on natural watersheds along large transport rivers, which has made it easier to control territories and ethnic groups. The Ottoman Empire, having inherited a large number of already developed powerful Black Sea shopping malls, does not aim to expand these networks with new facilities, but is gradually strengthening and modernizing them. Spatial transformations are hardly traded on the fabric of the city, and previous fortifications are stored in a significant amount of construction. 
At that time, a new system of territorial control was developed, its 3-tier hierarchical model allocating responsibility for the territory and socio-economic responsibilities of the controlled areas. The spread of small taboos and palanquins of the Budjak territory has not yet been discovered, since the territories are used in agriculture, but based on Romania's inheritance, it can be assumed that such a network also existed between the Bug and the Dniester. Other territories - Bessarabia - were controlled by the nomadic settlement of the Nogayans, who also formed armed support for the Crimean Khanate and the Ottoman Empire, protecting and regulating movement across the territories between the Dniester and the Dnieper. An important question to which is still unanswered is whether temporary fortified points were distributed among nomadic tribes, as the urban and fortification movement has not been identified at all.

\section{References}

[1] Bevz M., Frolova Y. 2017. Notes to the identification of the fortification systems in the cities of the southern Ukraine of 17 th -18 th centuries. Current issues in research, conservation and restoration of historic fortifications, № 9, pp. 342-347.

[2] Fedakar, C., 2015. Osmanl1-Rus Harplerinde Kılburun, Özi Nehri ve Hocabey Muharebeleri.. Karadeniz Araştırmaları, Issue 2, pp. 119-136.

[3] Finkel, Caroline and Victor Ostapchuk, 2005. Outpost of Empire: An Appraisal of Ottoman Building Registers as Sources for the Archeology and Construction History of the Black Sea Fortress of Özi. In Muqarnas: An Annual on the Visual Culture of the Islamic World, XXII, pp. 150-188.

[4] Freely, J. 2011. A History of Ottoman Architecture. s.1.:WIT.

[5] Gabor, A., n.d. Ottoman artillery and Europian military technology in 15th and 17th century. AOH, Issue 47, pp. 15-48.

[6] Greenhalgh, M. 2002. French Military Reconnaissance in the Ottoman Empire during the 18th and 19th Centuries as a Source for Our Knowledge of Ancient Monuments. The Journal of Military History, 66(2), pp. 359-388.

[7] Khodarkovsky, M. 2002. Russia's Steppe Frontier: The Making of Colonial Empire, 1300-1800. s.1.:Bloomington Indiana University Press.

[8] King, C. 2004. The Black Sea: A History. s.1.: Oxford University Press.

[9] Nicolle, D., 2010. Ottoman Fortifications 1300-1710. Oxford: Osprey Publishin.

[10] Ostapchuk V., Bilyayeva S. 2009. The Ottoman Northen Black Sea Frontier at Akkerman Fortress: The View from a Historical and Archaeological Project. Proceedings of the British Academy, Issue 156, pp. 137-170.

[11] Pepper, S. 2000. City Walls: The Urban Enceinte in Global Perspective. In: Ottoman military architecture in the early gunpowder era: A reassessment.. s.1.:s.n., pp. 283-316.

[12] Woodhead, C. 2012. The Ottoman World. Rotledge ed. s.1.: London.

[13] Brunov Y`Y`., Vlasyuk, Kaplun, Ky`pary`sova, Maksy`mov, Chy`nyakov, 1956. Y`story`ya russkoj arxy`tekturb. Moskva

[14] Sapozhny`kov, I. 2017. Konecz эроху` krepostej v severo-zapadnom Pry`chernomor`e. Scriptorium nostrum, 7(1), pp. 158-195.

[15] Sen`, D. 2018. Kromskoe xanstvo v konce XVII - nachale XVIII veka: vneshnyaya y` vnut-rennyaya poly`ty`ka v uslovy`yax nоvых y`story`chesky`x “vыzovov». Y`zvesty`ya Vuzov, Issue 2, pp. 88-95.

[16] Sereda, A. 2009. Sy`ly`sterensko-Ochakovsky`j eyalyat prez 18 - n na 20v.: Admy`ny`straty`vno - tery`tory`alno ustrojstvo, sely`shha y` naseleny`e a Severozapadnogo Pry`chernomory`e. Sofy`ya: Dy`o My`ra.

[17] Ty`mofy`enko, V. 1986. Formy`rovany`e gradostroy`tel`noj kul`turd Yuga Ukray`nы. Ky`ev: NY`Y`NTY`.

[18] Ty`mofiyenko, V. 1996. Rozplanuval`ni sy`stemy` pivdenny`x mist za ar-xivny`my` al`bomamy` kincya XVIII st.. Ukrayinoznavstvo, Issue 3, p. 130-155.

[19] Chebotarenko, G. 1989. Krepost` na Dnestre. s.l.

[20] Shkvary`kov, V. 1954. Ocherk y`story`y` plany`rovany`ya y`zastrojky` russky`x gorodov. Moskva:

[21] Yakovlev, V. 1931. Эvolyucy`ya dolgovremennoj forty`fy`kacy`y`. Moskva/

Юлія Фролова

\section{МЕРЕЖА ОСМАНСЬКИХ УКРІПЛЕНИХ МІСЦЬ ПІВНІЧНО-ЗАХІДНОГО УЗБЕРЕЖЖЯ ЧОРНОГО МОРЯ У XVII ТА XVIII ст.}

\footnotetext{
Атотація. Дослідження архітектурно просторового планування укріплених міст є частиною міждисииплінарного дослідження історично-містобудівного, культурно-сочіального та економікоприроднього характеру розвитку південного регіону сучасної України. Мистецтвво фортифікації упродовж 16-19 століть було важливим чинником впливу на розвиток міст, їх розміри та архітектурний вираз,
} 
соціальний та культурний склад території, символізували міліарну та політичну міцьь краӥни. Більшість міст північно-західного узбережжя Чорного моря за сочіально-економічних та політичних обставин мали лінії фортифікаиійних укріплень побудовані у різні часи та за різними фортифікаційними традиціями. У якостях фортифікаційних укріплень проявилась напрямок функиіонування поселення як потужни портів або торгівельних площ з використання розгалуженої системи підпорядкування оточуючої території та середмість. Дослідження охопило 11 міст, які мали фортифікації упродовж 17 століття. Було систематизовано історіографічні та описові документи щодо фортифікацій, зведено у табличну форму, проведено пошук спільних рис та алгоритмів утворення міського простору, порівняно з іншими відомими османськими містами того ж періоду. Отримані архітектурно-просторові моделі фортифікаційних укріплень об'єднуються у загальну мережу фортифікацій з тотожною організацією та підпорядкуванням міського простору за зразком державного рівня Османської Імперії, поділяються на другорядні та підпорядковані зв'язки. В залежності від природно-економічних чинників було виділено 4 типи фортифікаційних просторових зв'язків( брамовий, дзеркальний, ланцюговий та комбінований), обрані об'єкти мають спільні історичні та просторові характеристики (початок формування фортифікацій від літовського та генуєзьського періодів, татарська та ногайська перебудова, османська модернізація, період занепаду). Просторова єдність розвитку укріплених міст північно-західного узбережжя Чорного моря та їхні спільні архітектурно-просторові риси уможливлюють реконструкиію об' смного вигляду тих містечок, які мають обмежену джерельну базу. Також актуалізує питання перегляду містобудівного руху та характеру організаиї фортифікаиійних споруд у період володарювання Османської Iмперії XVII та ХVIII століття

Ключові слова: планування міста, фортеия, оборонна лінія, Південь України, укріплені поселення, північно-західне узбережжя Чорного моря, отаманські фортеці, ХVIII століття 